\title{
Validita a reliabilita akcelerometru S3+ pro měření rychlosti chůze a běhu systémem Polar RCX5
}

\section{Validity and reliability of $S 3+$ accelerometer for measuring the walking and running speed with Polar RCX5 system}

\author{
Jan Hnízdil, Martin Škopek, Zdeněk Havel
}

Pedagogická fakulta Univerzity Jana Evangelisty Purkyně, Ústí nad Labem

\begin{abstract}
Abstrakt:
Cílem studie bylo ověrit validitu a reliabilitu akcelerometru S3+. Ten je volitelnou součástí nového modelu kardiotachometru Polar RX5.

Čtyři vytrvalostní sportovci absolvovali na běhátkovém ergometru (0\% sklon) stupňovaný zátěžový test s počáteční rychlostí $5 \mathrm{kmh}^{-1}$ se zvýšením o $0,5 \mathrm{kmh}^{-1} \mathrm{každých} 200$ metrů. Test byl prováděn do odmítnutía od rychlosti $8 \mathrm{kmh}^{-1}$ byla direktivně chůze vystřídána běžeckou lokomocí. Pro stanovení míry stability měření byl test za obdobných podminek opakován.

Výsledky studie ukázaly, že pro běžeckou lokomoci chybovost přistroje je v rozmezí chyby udávané výrobcem (3\%). Pro chůzi je chybovost vyšši (10\%). Spolehlivost měřní byla ve všech sledovaných parametrech vysoká $(r>0,80)$ kromè stability měrení celkové vzdálenosti u chi̊ze $(r=0,53)$.
\end{abstract}

\begin{abstract}
:
The purpose of this study was to evaluate the validity and reliability of the accelerometer S3+. This is an optional part of the new model heart rate monitor Polar RX5.

Four endurance athletes completed the on treadmill ( $0 \%$ slope) graded exercise test with an initial speed of $5 \mathrm{kmh}^{-1}$ with the increase of $0.5 \mathrm{kmh}^{-1}$ every 200 meters. The test was conducted to rejection. From $8 \mathrm{kmh}^{-1}$ walking was directive turned to running locomotion. Test was repeated under similar conditions to determine the degree of measurement stability.

The study results showed that accuracy of running measurement is within the error provided by the manufacturer (3\%). For walking, the error rate is higher (10\%). Reliability of measurements was observed in all parameters is high $(r>0,80)$ except to the overall stability of the measurement of walking distance ( $r$ $=0.53)$.
\end{abstract}

Klíčová slova: akcelerometr, reliabilita, validita, chůze, běh

Key words: accelerometer, reliability, validity, walking, running

\section{ÚVOD}

V současné době je nejrozšířenější a zároveň nejpřístupnější metodou sledování a hodnocení intenzity zatížení monitorování srdeční frekvence. To je umožněno jednak technologickým pokrokem za posledních 20 let v oblasti pulsotachometrů, jejich miniaturizací, širokému spektru jednotlivých komerčních modelů i cenové dostupnosti.

Pásma intenzity zatížení vyjádřená $\mathrm{v}$ hodnotách srdeční frekvence, stanovená $\mathrm{v}$ rámci laboratorního vyšetření, nejsou vždy jednoznačně a jednoduše přenositelná do terénu. Srdeční frekvenci ovlivňuje řada vnitřních faktorů jako je aktuální zdravotní stav, psychoemoční zatížení (Hnízdil et al., 2003), biorytmus, tělesná teplota, hydratace, výživa. $Z$ vnějších faktorů jsou to např́iklad klimatické podmínky, nadmořská výška (Fox, 1996).

Jak dále např́iklad uvádí Stejskal (2006) „Sportovní trénink, který má mít z hlediska aerobní kapacity maximální efektivitu, nemůže být řízen srdeční frekvencí odpovídající maximálnímu setrvalému stavu laktátu (MLSS), ale spíše intenzitou zatížení, která tomuto stavu odpovídá. Řízení tréninku pomocí 
srdeční frekvence v podmínkách, kdy srdeční frekvence trvale překračuje hranici související s MLSS, je v praxi velmi obtížné, téměř nemožné“ (Stejskal, 2006).

Pro udržení intenzity, která odpovídá maximálnímu setrvalému stavu, je tedy vhodnější, jak plyne z výše uvedeného, využít jiných prostředků. Monitorovat intenzitu zatížení lze např. ve vztahu rychlost/čas, rychlost vzdálenost, nebo výkon/čas. Díky miniaturizaci a modernizaci nejnovějších přístrojů není toto monitorování omezeno pouze na podmínky laboratorních vyšetření, ale lze je přenést do terénu a každodenní tréninkové praxe. Jednotlivé dostupné prostředky jsou vázány na konkrétní pohybovou aktivitu.

Z hlediska komplexního monitoringu se jeví jako optimální spojení monitoru srdeční frekvence s dalším zařízením na sledování dalších ukazatelů intenzity pohybové činnosti.

$\mathrm{V}$ praxi jsou využívány tyto technické prostředky:

a) Pedometry (krokoměry)

Př́stroje fungující na principu pružiny registrují změnu pohybu (krok) ve vertikální ose. Z tohoto důvodu nejsou vhodné pro pohybové aktivity, při kterých dochází k minimálnímu vertikálnímu pohybu. Výhodou pedometrů je jejich cenová dostupnost. Většina současných modelů je vybaveny algoritmy pro přepočet energetické náročnosti pohybu. Tento údaj je však nutné brát jako orientační.

Cenová dostupnost, jednoduchost v ovládání a manipulace umožňuje využít ve větší míře monitorování pohybového režimu jak u zdravých osob, tak poprrípadě u pacientů (Máček a Radvanský, 2011). Sledovatelná pohybová aktivita je však omezena pouze na bipední lokomoci.

b) Akcelerometry - elektronické detektory pohybu

Akcelerometry na rozdíl od krokoměrů registrují přímo zrychlení, novější typy přístrojů již ve třech osách, což zpřesňuje naměřené údaje i u pohybu s častou změnou směru. Měř́ jak statické, tak i dynamické zrychlení. Statické zrychlení je vázáno na zrychlení tíhové a dynamické zrychlení je způsobeno změnou rychlosti pohybu. Na rozdíl od pedometrů a GPS modulů (viz dále) lze pomocí akcelerometrů kromě rychlosti lokomoce monitorovat i délku a frekvenci kroků.

Tyto př́stroje mohu po aplikaci predikčních rovnic vypočítávat i energetickou spotřebu. Při hodnocení energetického výdeje je však nutné počítat s limity výpovědní hodnoty. Zejména př̌i vyšších rychlostech validita ke kritériu energetického výdaje klesá (Psotta et al., 2007).

Výhodou je možnost exportu dat do osobního počítače, at už v rámci komerčních aplikací vázaných na pracovní stanici nebo s využitím on-line služeb. Tak lze dále zpracovávat a hodnotit naměřená data.

c) Využití GPS modulu

Záznam trasy pohybu s využitím satelitní navigace je relativně nová metoda, v praxi již však běžně užívaná. Chybějí zatím validační studie na toto téma. Kvalita GPS signálu je rozhodující pro přesnost získaných dat. S rychlým rozvojem a nástupem nových technologií se i ta dále zvyšuje. S úspěchem ji lze použit $\mathrm{u}$ pohybových aktivit, kde nedochází $\mathrm{k}$ typickému pohybu detekovatelnému tříosým akcelerometrem (in-line bruslení, pádlování, popř. pohyb v členitém terénu). Využitelnost metody stoupá v propojení s kvalitními mapovými podklady pro další zpracování naměřených dat.

V rámci našeho výzkumu jsme se zaměřili na reliabilitu a validitu monitorování rychlosti lokomoce za použití tř́íosého akcelerometru S3+ v rámci systému Polar RCX5.

Cílem studie je přispět $\mathrm{k}$ řešení problematiky reliability a validity akcelerometrů, úkolem stanovit míru reliability a validity akcelerometru Polar S3+ pro měření rychlosti běhu a chůze.

\section{METODIKA:}

Výzkumný soubor tvořili 4 trénovaní vytrvalci (orientační běžci a běžci na lyžích) ve věku 26,6 r. (s = $10,2)$. Všichni v době výzkumu pravidelně trénovali (3-5 týdně), všichni již v minulosti absolvovali zátě- 
žové funkční vyšetření na motorizovaném běžeckém ergometru HP Cosmos Venus (HP Cosmos Sports and Medical, SRN) v laboratoři, kde se uskutečnil samotný výzkum. Před započetím samotného výzkumu byl běžecký ergometr kalibrován v rámci pravidelného servisu odbornou firmou.

\section{Nástroje}

Předmětem zkoumání je funkce tříosého akcelerometru 3S+ v modelu Polar RCX5 (Polar, Oy Kempele, Finsko). Akcelerometr má podobu nožního snímače oválného tvaru o rozměrech $55 \times 38 \mathrm{~mm}$. Výrobek je na trh uváděn ve dvou provedeních. Jednak pro př́ímé vložení do speciální běžecké obuvi, jednak pro připevnění na nárt do systému šněrování boty. Tato varianta modelu byla předmětem našeho zkoumání. Dle pokynů výrobce $\mathrm{v}$ manuálu $\mathrm{k}$ použití senzoru byl při všech testech připevněn na levý nárt testované osoby a zajištěn integrovaným mechanismem proti posunu ze stabilní pozice. Varianta senzoru S3+ se liší od předchozí verze S3 pouze v systému uchycení na šněrování boty. Z hlediska funkce prŕístroje lze považovat oba modely za totožné.

Akcelerometr využívá frekvenci měření $2,4 \mathrm{GHz}$ a digitální přenos dat do přijímače Polar RCX5. Následně jsou data přenositelná do PC pro analýzu s využitím software Polar Pro Trainer 5 stejného výrobce.

Kalibrace senzoru S3+ byla provedena podle pokynů výrobce. Předepisuje uběhnout trasu o známé vzdálenosti (doporučeno více než $1000 \mathrm{~m}$ ) se současným měřením nekalibrovaného čidla. Kalibrační faktor získáme výpočtem ze vztahu:

skutečná délka uběhnutého úseku

délka indikovaná systémem POLAR

Při uběhnuté vzdálenosti 1000 metrů a naměřené vzdálenosti systémem POLAR např. 1180 metrů je kalibrační faktor roven hodnotě 0,983 . Kalibrační faktor může nabýt hodnoty v rozmezí 0,500-1,500. Výrobce uvádí chybu nekalibrovaného přístroje $\pm 3 \%$, po kalibraci přesnost ještě vzrůstá. „Definice se vztahuje na stabilní podmínky“ (Polar, 2010).

Kalibrace v rámci naší studie proběhla za konstantní rychlosti pásu běhátka $11 \mathrm{~km} \cdot \mathrm{h}^{-1}$, kterou probandi absolvovali vzdálenost 2000 metrů. Tato fáze zároveň sloužila jako rozcvičení před samotným stupňovaným testem. Kalibrační úsek byl zahájen již z plné rychlosti běhátka. Fáze od nulové rychlosti po požadovanou rychlost $11 \mathrm{~km} \cdot \mathrm{h}^{-1}$ tedy byla eliminována.

Kalibrační faktory, které byly použity u jednotlivých probandů, jsou uvedeny v tabulce 1 .

Tabulka 1. Kalibrační faktory jednotlivých probandů (kalibrační úsek $2000 \mathrm{~m}$, rychlost $11 \mathrm{~km} \cdot \mathrm{h}^{-1}$ )

\section{Provedení testu:}

\begin{tabular}{|c|c|}
\hline proband & kalibrační faktor \\
\hline $\mathrm{A}$ & 0,951 \\
\hline $\mathrm{B}$ & 0,981 \\
\hline $\mathrm{C}$ & 0,967 \\
\hline $\mathrm{D}$ & 0,988 \\
\hline
\end{tabular}

Po absolvování kalibračního úseku o délce $2000 \mathrm{~m}$ rychlostí $11 \mathrm{~km} \cdot \mathrm{h}^{-1}$ byly vypočítány hodnoty kalibračního koeficientu a provedena kalibrace akcelerometru. Tato hodnota byla použita pro oba následné testy.

Každý proband absolvoval dvakrát (s odstupem 3 dnů) stupňovitý zátěžový test iniciální rychlostí 5 $\mathrm{km} \cdot \mathrm{h}^{-1}$ se zvýšením rychlosti každých $200 \mathrm{~m}$ o $0,5 \mathrm{~km} \cdot \mathrm{h}^{-1}$. Test byl prováděn do odmítnutí, maximální dosažené rychlosti byly v rozmezí $16-19,5 \mathrm{~km} \cdot \mathrm{h}^{-1}$. V rozmezí rychlostí $5-7,5 \mathrm{~km} \cdot \mathrm{h}^{-1}$ byla požadována chůze, od rychlosti $8 \mathrm{~km} \cdot \mathrm{h}^{-1}$ běh. Sklon běhátka byl $0 \%$. 
Druhý test s odstupem 3 dnů absolvovali probandi ve stejné obuvi, se shodným umístěním senzoru na obuvi a za obdobných podmínek (doba testování, oblečení, apod.)

Počáteční rychlost běžeckého ergometru byla $4,5 \mathrm{~km} \cdot \mathrm{h}^{-1}$, start záznamu a ukládání dat $\mathrm{z}$ akcelerometru do náramkového přijímače bylo zahájeno po prvních $200 \mathrm{~m}$ při rychlosti $5 \mathrm{~km} . \mathrm{h}^{-1}$. Každých uběhnutých 200 metrů bylo signalizováno akustickým systémem běžeckého ergometru s následným zvýšením rychlosti. Každé zvýšení označil proband do paměti přistroje stisknutím tlačítka na náramkových hodinkách jako mezičas.

\section{Zpracování dat}

Po skončení testu byla data analyzována prostřednictvím softwaru Polar Professional Trainer ver. 5. V rámci grafického a tabelárního zobrazení naměřených dat byly zaznamenány průměrné rychlosti a vzdálenosti na jednotlivých dvousetmetrových úsecích. Ty pak byly srovnány s referenční metodou, tj. údaji z běhátkového ergometru. Do výpočtu byla zahrnuta data pro rozmezí rychlosti chůze a běhu v rozmezí 5-16 km.h $\mathrm{h}^{-1}$ (vzhledem k nejnižší maximální dosažené rychlosti $16 \mathrm{~km} \cdot \mathrm{h}^{-1}$ ).

\section{Statistické metody}

1. Metoda test-retest. Spolu se základními statistickými ukazateli polohy a variability byl použit Pearsonův korelační koeficient pro stanovení míry reliability.

2. Empirická validita byla posouzena vzhledem ke kritériu (referenční metodě) rychlosti udávané systémem běhátka. Protože korelační koeficient vyjadřuje pouze závislost obou metod, byl pro posouzení shody výsledků využit Bland-Altmanův graf, tj. grafická analýza pomocí modifikace grafu reziduálních hodnot pro regresi. Při použití tohoto grafu a při odhalení trendu v rozdílech $(\mathrm{x}-\mathrm{y})$ je třeba vypočítat korelaci mezi hodnotami $(\mathrm{x}-\mathrm{y})$ a $(\mathrm{x}+\mathrm{y}) / 2$ a její statistickou významnost pro posouzení proporcionální chyby (Hendl, 2006). Metody bez významné odchylky obsahují v intervalu $\pm 1,96$ s nulovou hodnotu (Rajdl, 2009).

Pro statistické zpracování byl použit program MedCalc ver.12.1 (MedCalc software).

\section{VÝSLEDKY}

\section{Reliabilita měření}

Tabulka 2. Průměrné hodnoty rychlosti, délky a frekvence kroku a délky počítané z jednotlivých 200m úseků ve stupňovaném chodeckém testu. Plus absolutní vzdálenost. Iniciální rychlost $5 \mathrm{kmh}^{-1}$, konečná rychlost $7,5 \mathrm{kmh}^{-1}$, délka úseku $200 \mathrm{~m}$. Skutečná celková vzdálenost (data z běhátka) je 1200 metrů, rychlost $6,25 \mathrm{~km} \cdot \mathrm{h}^{-1}$.

\begin{tabular}{|c|c|c|c|c|c|c|c|c|c|c|}
\hline & \multicolumn{2}{|c|}{ rychlost $\mathbf{k m h}^{-1}$} & \multicolumn{2}{c|}{ délka kroku m } & \multicolumn{2}{c|}{ frekvence } & \multicolumn{2}{c|}{$\begin{array}{c}\text { délka 200m } \\
\text { úseku m }\end{array}$} & \multicolumn{2}{c|}{ délka celkem m } \\
\hline Proband & test & retest & test & retest & test & retest & test & retest & test & retest \\
\hline $\mathrm{A}$ & 6,67 & 6,78 & 0,91 & 0,92 & 60,67 & 60,00 & $\begin{array}{c}214,83 \\
\mathrm{~s} 4,56\end{array}$ & $\begin{array}{c}218,83 \\
\mathrm{~s} 4,48\end{array}$ & 1289 & 1313 \\
\hline $\mathrm{B}$ & 6,83 & 6,90 & 0,89 & 0,92 & 61,83 & 62,01 & $\begin{array}{c}219,67 \\
\mathrm{~s} 2,98\end{array}$ & $\begin{array}{c}220,88 \\
\mathrm{~s} \mathrm{2,80}\end{array}$ & 1318 & 1340 \\
\hline $\mathrm{C}$ & 6,80 & 6,92 & 0,75 & 0,72 & 62,35 & 62,89 & $\begin{array}{c}220,01 \\
\mathrm{~s} \mathrm{3,34}\end{array}$ & $\begin{array}{c}219,81 \\
\mathrm{~s} \mathrm{3,76}\end{array}$ & 1341 & 1330 \\
\hline $\mathrm{D}$ & 6,65 & 6,69 & 0,70 & 0,68 & 64,01 & 64,57 & $\begin{array}{c}218,89 \\
\mathrm{~s} 4,01\end{array}$ & $\begin{array}{c}220,60 \\
\mathrm{~s} 3,22\end{array}$ & 1310 & 1301 \\
\hline
\end{tabular}


Tabulka 3 Koeficienty reliability (stability) u vybraných parametrů chůze $\left(5-7,5 \mathrm{~km} \cdot \mathrm{h}^{-1}\right)$ měřených akcelerometrem S3+

\begin{tabular}{|c|c|c|c|c|c|}
\hline & $\begin{array}{c}\text { rychlost } \\
\mathbf{k m h}-\mathbf{1}\end{array}$ & $\begin{array}{c}\text { délka kroku } \\
\mathbf{m}\end{array}$ & frekvence & $\begin{array}{c}\text { délka } \mathbf{2 0 0 m} \\
\text { úseku } \mathbf{~ m}\end{array}$ & $\begin{array}{c}\text { délka celkem } \\
\mathbf{~ m}\end{array}$ \\
\hline $\mathrm{r}$ & 0,94 & 0,99 & 0,98 & 0,80 & 0,53 \\
\hline
\end{tabular}

Tabulka 4. Průměrné hodnoty rychlosti, délky a frekvence kroku a délky počítané z jednotlivých 200m úseků ve stupňovaném běžeckém testu. Plus absolutní vzdálenost. Iniciální rychlost $8 \mathrm{~km} \cdot \mathrm{h}^{-1}$, konečná rychlost $16 \mathrm{~km} \cdot \mathrm{h}^{-1}$, délka úseku $200 \mathrm{~m}$. Skutečná uběhnutá vzdálenost (data z běhátka) je $3400 \mathrm{~m}$, rychlost $12 \mathrm{~km} \cdot \mathrm{h}^{-1}$.

\begin{tabular}{|c|c|c|c|c|c|c|c|c|c|c|}
\hline & \multicolumn{2}{|c|}{ rychlost kmh-1 } & \multicolumn{2}{c|}{ délka kroku m } & \multicolumn{2}{c|}{ frekvence } & \multicolumn{2}{c|}{$\begin{array}{c}\text { délka 200m } \\
\text { úseku m }\end{array}$} & \multicolumn{2}{c|}{ délka celkem m } \\
\hline Proband & test & retest & test & retest & test & retest & test & retest & test & retest \\
\hline A & 11,71 & 11,92 & 1,20 & 1,22 & 79,88 & 79,64 & $\begin{array}{c}195,17 \\
\text { s 7,02 }\end{array}$ & $\begin{array}{c}200,35 \\
\text { s 3,22 }\end{array}$ & 3324 & 3406 \\
\hline B & 12,19 & 12,25 & 1,12 & 1,13 & 87,76 & 88,52 & $\begin{array}{c}203,47 \\
\text { s 2,99 }\end{array}$ & $\begin{array}{c}201,32 \\
\text { s 4,22 }\end{array}$ & 3459 & 3448 \\
\hline C & 11,85 & 11,94 & 1,11 & 1,09 & 89,56 & 88,21 & $\begin{array}{c}197,88 \\
\text { s 5,2 }\end{array}$ & $\begin{array}{c}201,12 \\
\text { s 4,22 }\end{array}$ & 3460 & 3480 \\
\hline D & 11,65 & 11,60 & 1,15 & 1,19 & 82,00 & 81,21 & $\begin{array}{c}195,01 \\
\text { s 5,12 }\end{array}$ & $\begin{array}{c}200,35 \\
\text { s 3,55 }\end{array}$ & 3405 & 3424 \\
\hline
\end{tabular}

Tabulka 5. Koeficienty reliability (stability) u vybraných parametrů běžecké lokomoce $\left(8-16 \mathrm{~km} \cdot \mathrm{h}^{-1}\right)$ měřených akcelerometrem $\mathrm{S} 3+$.

\begin{tabular}{|c|c|c|c|c|c|}
\hline & $\begin{array}{c}\text { rychlost } \\
\mathbf{k m h - 1}\end{array}$ & $\begin{array}{c}\text { délka kroku } \\
\mathbf{m}\end{array}$ & frekvence & $\begin{array}{c}\text { délka 200m } \\
\text { úseku } \mathbf{~ m}\end{array}$ & $\begin{array}{c}\text { délka celkem } \\
\mathbf{m}\end{array}$ \\
\hline $\mathrm{r}$ & 0,92 & 0,94 & 0,98 & 0,90 & 0,87 \\
\hline
\end{tabular}

\section{Validita měření}

Obrázek 1. Bland-Altmanův graf charakterizující ekvivalentnost měření rychlosti chůze a běhu $\mathrm{v} \mathrm{km} \cdot \mathrm{h}^{-1}$ senzorem $\mathrm{S}^{+}$a referenční metodou $(\mathrm{RM})$, tedy rychlosti udávané systémem běhátka. Hodnocena

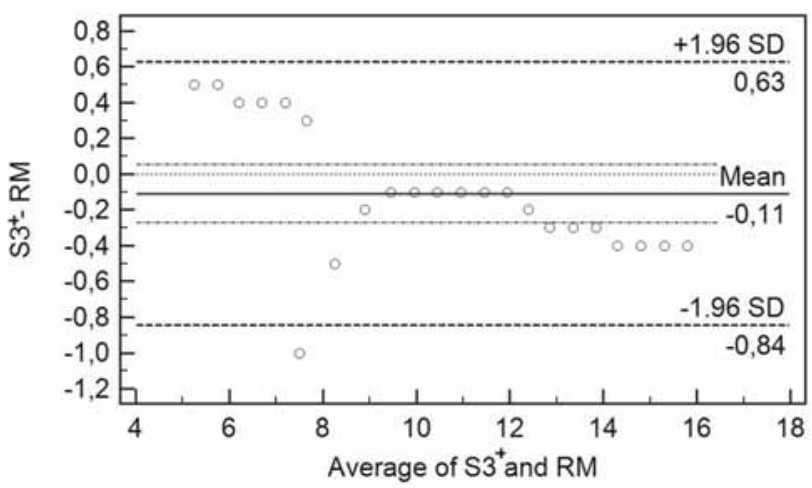


je rychlost běhu stanovená oběma metodami. Na ose $\mathrm{x}$ jsou průměry, na ose y rozdíly př́islušných dvojic měření. Hranice mezi chůzí a během byla stanovena na $8 \mathrm{~km} . \mathrm{h}^{-1}$.

S rostoucí či naopak klesající rychlostí od kalibrační rychlosti $\left(11 \mathrm{~km} . \mathrm{h}^{-1}\right)$ dochází k růstu diference naměřených hodnot. Významnější diference nalezneme v levé části grafu u hodnot rychlosti, které odpovídají chůzi. Přesto jsou všechny hodnoty umístěny uvnitř konfidenčního intervalu, což společně s faktem, že nulová hodnota leží v intervalu $\pm 1,96 \mathrm{~s}$, vypovídá o podobnosti obou metod.

\section{DISKUSE}

Základním výstupem naší práce je zjištění, že rychlost lokomoce (běžecké i chodecké) detekované akcelerometrem S3+ systému Polar RX se signifikantně neliší od hodnot referenčního systému, tj. běhátkového ergometru. Dále byla zjištěna vysoká míra stability jednotlivých komponent - rychlosti, vzdálenosti, frekvence a délky kroku (rozpětí r $0,95-0,98$ ). Míra přesnosti běžecké lokomoce $\pm 3 \%$, tak jak ji uvádí výrobce (Polar, 2010), byla potvrzena i v naší studii.

Obdobný výzkum provedli Hausswirth et al. (2009). Zaměřili se na validitu a stabilitu měření v pásmu od 12 do $18 \mathrm{~km} . h^{-1}$ výše. Výsledky jejich šetření ukazují na vysokou míru přesnosti a spolehlivosti akcelerometru S3, která není ovlivněna vyšší či nižší rychlostí běžecké lokomoce.

Nás zajímala i validita vzhledem $\mathrm{k}$ nižším rychlostem, odpovídajícím chůzi a přechodu mezi chůzí a během $\left(6-8 \mathrm{~km} \cdot \mathrm{h}^{-1}\right)$. Zde byla chybovost oproti běžecké lokomoci vyšší. Maximálních chyba $10 \%$ byla detekována na úrovni rychlosti chůze $5,5 \mathrm{~km} \cdot \mathrm{h}^{-1}$. Nejnižší hodnota korelačního koeficientu $(0,53)$ vyjadřující míru stability testu je spojená také s chůzí - konkrétně se stabilitou měření celkové vzdálenosti testu. To jde částečně na vrub nízkému počtu testovaných, nebot korelační koeficient je veličina citlivá na rozsah souboru (Hendl, 1997). Jak je však patrné z Bland-Altmanova grafu, měření chodecké lokomoce prostřednictvím akcelerometru S3+ je zatíženo vyšší chybovostí oproti běhu.

Přestože statisticky se obě metody od sebe neliší, je pro další využití tohoto akcelerometru v praxi vždy nutné posoudit věcnou významnost a velikost chyby, jaká ještě může být pro následné využití, šetření a výzkumy akceptovatelná.

Pozitivní z hlediska validity měření je fakt, že jednotlivé rychlosti lokomoce na př́íslušných dvousetmetrových úsecích byly signifikantně odlišné $(\mathrm{p}<0,05)$ v celém průběhu stupňovaného testu, což vyvrací pochybnosti některých autorů (Brage et al., 2003) o nepřesnosti zejména vertikální osy akcelerometrů ve vyšších rychlostech.

Jak jsme se již zmínili v úvodu, korektní monitoring rychlosti lokomoce má úlohu zejména v těch energetických hladinách, kdy se již kontrola intenzity pouze na základě hodnot srdeční frekvence stává neúčinnou či nepřesnou. Považujeme za vhodné využít v těchto pásmech na úrovni MLSS namísto indikátoru srdeční frekvence právě kontrolu intenzity prostřednictvím akcelerometru. Vhodnou volbou se jeví kombinace a paralelní využití obou systémů. Na tom jsou ostatně založeny i poslední modely kardiotachometrů. Stávající monitoring srdeční frekvence lze rozšírit o data $\mathrm{z}$ akcelerometrů, popř́padě z modulu GPS (viz úvod).

Ve sportovní praxi naleznou využití i data kvantifikující další komponenty běžecké lokomoce, jako jsou frekvence a délka kroku. Tyto dva faktory se podílejí na optimální běžecké technice spojené s efektivní ekonomikou pohybu (Hausswirth et al., 2009). Jak uvádí (Saito et al., 1974), trénovaní běžci zvyšují rychlost běhu do $7 \mathrm{~m} \cdot \mathrm{s}^{-1}$ prodlužováním kroku. Netrénovaní běžci pouze do $5,5 \mathrm{~m} \cdot \mathrm{s}^{-1}$. Další zvyšování rychlosti je realizováno již jen zvýšením frekvence běžeckého kroku.

Proces prodlužování a zkracování běžeckého kroku má důležitý efekt na aktivní svalovou hmotu podílející se na pohybu, přičemž při záměrné stimulaci v rámci tréninkových metod lze očekávat změny 
v efektivitě běžecké lokomoce (Hausswirth et al., 2009), uvádí (Saito et al., 1974). Akcelerometr tak může být využit v rámci tohoto specifického tréninku jako prostředek monitoringu i následné zpětné vazby.

V rámci analýzy námi naměřených dat byla pozorována i anomálie při prvním dvousetmetrovém běžeckém úseku. Běh byl probandy realizován od rychlosti běžeckého pásu $8 \mathrm{~km} \cdot \mathrm{h}^{-1}$ kontinuálně po „chodeckém“ úseku na rychlosti $7,5 \mathrm{~km} \cdot \mathrm{h}^{-1}$. U všech probandů se projevilo větší či menší kolísání rychlosti (obr. 2), které nemělo obdobu v žádné části chodecké, ani následné běžecké lokomoce. Nejsme schopni uspokojivě vysvětlit tento jev, spekulativně však souvisí s konstrukcí a principem setrvačnosti daného typu akcelerometru.

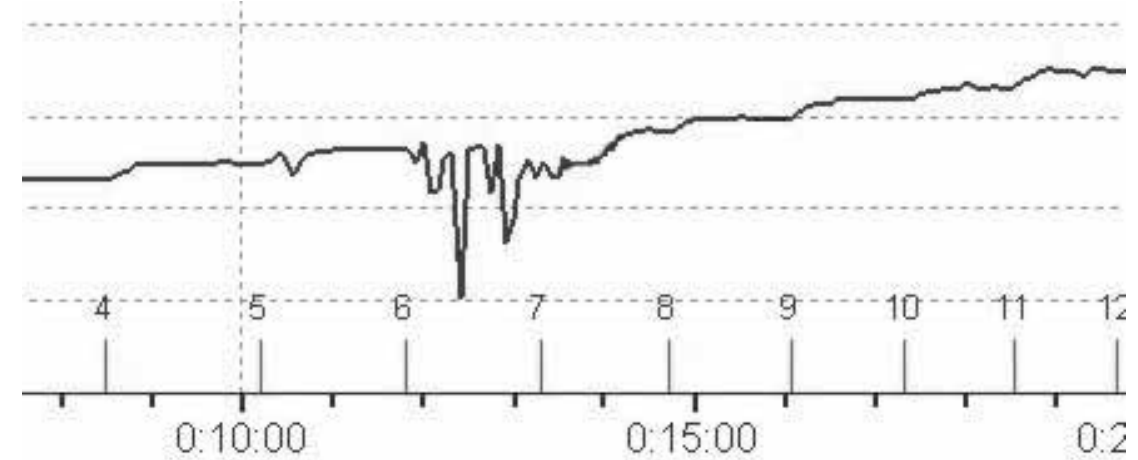

Obrázek 2 Kolísání rychlosti na prvním běžeckém dvousetmetrovém úseku. Na obr. mezi body 6 a 7 rychlost běhátkového ergometru $8 \mathrm{~km} \cdot \mathrm{h}^{-1}$.

Výpovědní hodnoty našeho výzkumu limituje malý počet probandů, což ovlivňuje zejména výpočet korelačního koeficientu pro určení stability jednotlivých parametrů. Studii chápeme jako pilotní, přičemž otázkami dalšího výzkumu na tomto poli jsou přesnost měření v terénních podmínkách, při různém sklonu podložky, pohyb mimo zpevněné cesty, chůze se změnou směru. Předmětem dalšího zkoumání v této oblasti by se měla stát i validita a reliabilita akcelerometrů při rychlostech chůze nižších než $5 \mathrm{~km} \cdot \mathrm{h}^{-1}$, respektive vyšších než $16 \mathrm{~km} \cdot \mathrm{h}^{-1}$.

\section{ZÁVĚRY}

Prokázali jsme, že akcelerometr S3+v systému nového kardiotachometru Polar RX5 poskytuje validní data charakterizující běžeckou lokomoci v rychlostech $8-16 \mathrm{~km} \cdot \mathrm{h}^{-1}$. Chybovost tohoto systému nepřekračuje údaj uváděný výrobcem $( \pm 3 \%)$. Míra spolehlivosti detekce jednotlivých parametrů - rychlosti běhu, vzdálenosti, frekvence i délky běžeckého kroku - je vysoká. Oproti tomu určité limity výpovědní hodnoty s sebou nese měření rychlosti chůze, kde se velikost chyby pohybuje okolo $10 \%$. Tato zjištění považujeme za nutné doplnit o další šetření, která obsahově naváží na naši pilotní studii.

\section{Literatura}

BRAGE, S., WEDDERKOPP, N., FRANKS, P. W., ANDERSEN, L. B., FROBERG, K. (2003). Reexamination of validity and reliability of the CSA monitor in walking and running. Med Sci Sports Exerc. 35, 2003, stránky 1447-54.

FOX, I S. (1996). Human physiology. New York : The McGraw-Hill Companies, Inc, 1996.

HAUSSWIRTH, CH. et al. (2009). Accuracy and Repatability of the Polar RS800sd to evaluate stride rate and runing speed. Int J Sports Med. 30(5), 2009, stránky 354-359.

HENDL, J. (2006). Přehled statistických metod. Praha : Portál, 2006. 
HNÍZDIL, J., KUBÁTOVÁ, J. a PYŠNÝ, L. (2003). Psychoemoční zatížení vyjádřené kinetikou srdeční frekvence při extrémním sportu. Ed. M. KAVALÍŘOVÁ, J. KIRCHNER. Nové perspektivy výzkumu a praxe v kinantropologii. Praha: FTVS UK, 2003.

MÁČEK, M., RADVANSKÝ, J. (2011). Fyziologie a klinické aspekty pohybové aktivity. Praha : Galén, 2011. Polar. (2011). S3+ sensot W.I.N.D. User manual. Polar. [Online] 2011. [Citace: 12. prosinec 2011.] http:// www.polar.fi/e_manuals/s3+_Stride_Sensor/Polar_s3+_stride_sensor_accessory_manual_English.pdf. PSOTTA, R.,VODIČKA, P., HELLER, J., SOUKUP, V. (2007). Validita a reliabilita akcelerometru ACTIGRAF model GT1M: pilotní studie. Česká kinantropologie. 2, 2007.

RAJDL, D. (2009). OVAVT Online. E-lerningový portál LF Plzeň. [Online] LF UK Plzeň, 2009. [Citace: 4. Leden 2011.] http://ovavt.lfp.cuni.cz/mod/glossary/print.php?id=9999\&mode=author\&hook=ALL\&sort key=FIRSTNAME\&sortorder $=$ asc\&offset $=-10$.

STEJSKAL, P. (2006). Konec tradičního pojetí energetických zón? Efekty pohybového zatížení v edukačním prostředí tělesné výchovy a sportu. Olomouc: UP, 2006. 